\title{
Correlation of ß-catenin expresssion and metastasis in tongue squamous cell carcinoma ${ }^{1}$
}

\author{
Correlação da expressão da ß-catenina e presença de metástases em carcinoma de células \\ escamosas de língua
}

\author{
Roseana de Almeida Freitas ${ }^{I}$, Ericka Janine Dantas Silveira' ${ }^{\mathrm{II}}$, João Paulo Borges da Silveira ${ }^{\mathrm{III}}$, Fabyanne Mazutti da Silva ${ }^{\mathrm{II}}$, \\ Rivadávio Fernandes Batista de Amorim ${ }^{\mathrm{IV}}$
}

\begin{abstract}
${ }^{I}$ DDS, MSc, PhD, Full Professor, Postgraduate Program in Oral Pathology, School of Dentistry, UFRN, Natal-RN, Brazil.

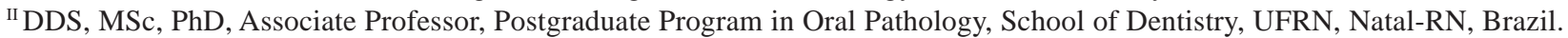

III Graduate Student, School of Medicine, University of Brasilia (UnB), Brasilia-DF, Brazil.

${ }^{\text {Iv }}$ DDS, MSc, PhD, Associate Professor, Department of Pathology, School of Medicine, UnB, Brasilia-DF, Brazil.
\end{abstract}

\begin{abstract}
Purpose: It has been reported that the oral squamous cell carcinoma (OSCC) in tongue shows a more infiltrative profile, aggressive clinical course and poor prognosis, which may be related to a higher metastatic potencial. The aim of the present study was to assess the expression of ß-catenin in OSCC of the tongue and its correlation with tumor metastasis. Methods: Twenty four cases were selected and divided in two groups: metastatic group $(n=12)$ and non-metastatic group $(n=12)$. A semi-quantitative analysis of the $\beta$-catenin expression was performed in the invasive tumor front and cases were graded as follows: negative (score 0 ), positive (score + ), and strongly positive (score ++ ). Results: It was detected that $33 \%, 50 \%$ and $17 \%$ of the cases in metastatic group were scored 0 , + and ++ , respectively, and the non-metastatic group showed that $42 \%$ were scored “ 0 ”, $33 \%$ scored + and $25 \%$ scored ++ . Statistical analysis showed no diference between the studied groups. Conclusions: Based on these results, it can be concluded that the immunoexpression of ß-catenin does not represent a valuable tool to predict metastatic potencial of OSCC in tongue.
\end{abstract}

Key words: Carcinoma, Squamous Cell. Tongue. Neoplasm Metastasis. beta Catenin. Cell Adhesion.

\section{RESUMO}

Objetivo: O carcinoma de células escamosas (CCE) quando presente em língua exibe aspecto mais infiltrativo, curso clínico agressivo e prognóstico desfavorável. Tais características podem associar-se com maior potencial metastático. O presente trabalho teve como meta investigar a expressão de ß-catenina em CCE de língua e sua relação com o desenvolvimento de metástases. Métodos: Foram selecionados 24 casos de CCE em língua e divididos em dois grupos: grupo metastático (n=12) e grupo sem metástase (n=12). Realizou-se uma análise semi-quantitativa da imunoexpressão da ß-catenina no fronte invasivo tumoral e sendo considerada como negativa, positiva e fortemente positiva, atribuindo-se os escores, “0”, “+” e “++”, respectivamente. Resultados: A expressão de $ß$-catenina apresentou, no grupo metastático, escore “0” em 33\% dos casos, escore “+” em 50\% dos casos e escore “++” em 17\% dos casos; e, no grupo sem metástase, escore “0” em 42\% dos casos, escore “+” em 33\% dos casos e escore “++” em 25\% dos casos. A análise estatística não demonstrou nenhuma diferença signficativa entre a expressão da proteína nos dois grupos. Conclusão: Diante destes resultados, concluiu-se que a expressão da ß-catenina não constitui um método eficaz, isoladamente, para predizer o potencial metastático do CCE em língua.

Descritores: Carcinoma de Células Escamosas. Língua. Metástase Neoplásica. beta Catenina. Adesão Celular.

${ }^{1}$ Research perfomed at Postgraduate Program in Oral Pathology, Department of Odontology, Federal University of Rio Grande do Norte (UFRN), Brazil.

\section{Introduction}

Oral squamous cell carcinoma (OSCC) represents over $90 \%$ of malignant tumors of the oral mucosa ${ }^{1}$. There are strong clinical evidences that OSCC has a worse prognosis when present in the tongue. Moreover, it usually shows a more infiltrative invasion and, therefore, predispose to the formation of metastasis ${ }^{2}$.

Tumor invasion and metastasis formation involve a series of steps including proteolytic degradation of basement membrane and extracellular matrix, changes in cell adhesion and tumor cells movement on tissues ${ }^{3}$. In particular, it has been suggested that the reduction of cell adhesion mediated by ß-catenin/ E-cadherin complexes is associated with the development and progression of squamous cell carcinomas of the head and neck ${ }^{4}$.

ß-catenin is a multifunctional protein crucial both in regard to cell-cell adhesion and also in transduction of cellular signals. A junctional portion of $ß$-catenin links E-cadherin to alpha-catenin and consequently to the structure of the actin 
microfilaments of the cytoskeleton; playing this way a very representative role with respect to cell adhesion. Corroborating this importance, several studies have shown that deregulation of cadherin-catenin complex, in addition to reduced expression of ß-catenin, is present in several types of malignancies, especially those of a more aggressive nature and a higher metastatic potential $^{5.6}$.

On the other hand, non-junctional portionof ß-catenin is rapidly phosphorylated and degraded in the cytoplasm. However, the activation of the Wnt induces the stabilization of cytoplasmic ß-catenin, facilitating its translocation to the nuclei. In the nuclei, the protein binds to members of the family of transcription factors T-cell factor/ lymphoid enhancer factor - TCF/LEF ${ }^{6}$. Such deposits can contribute to the development of malignancies ${ }^{7}$.

Thus, this study was to evaluate the immunohistochemical expression of ß-catenin in squamous cell carcinoma of tongue with and without metastasis, in order to establish a correlation between the expression of this protein and the tumor metastatic potential.

\section{Methods}

\section{Sample selection}

To perform this study, 24 cases of OSCC were selected from Pathology-Anatomy Service, Oral Pathology Department, Federal University of Rio Grande do Norte. The cases were divided into two groups: with metastasis $(n=12)$ and without metastasis $(n=12)$. It was used, as a randomization criterion for inclusion in each group, the presence or absence of regional or distant metastasis at the time of diagnosis or before the initial therapeutic protocol.

\section{Immunohistochemistry}

Histological sections of $3 \mu \mathrm{m}$ in thickness were obtained from tissue samples fixed in $10 \%$ formalin and embedded in paraffin. The specimens were processed by the immunohistochemical technique by the streptavidin-biotin method, using anti-ß-catenin polyclonal antibodie at a dilution of 1:500 (Ab-1 clone, LabVision/ Neomarkers). The sections were subjected to antigen retrieval through steamer treatment, for 25 minutes, in citric acid ( $\mathrm{pH}$ 6.0). After incubation with primary, secondary antibodies and streptavidin-biotin complex (DAKO, A/S, Glostrup, Denmark), revelation of the sections using a diaminobenzidine chromogen solution and a counter-staining with Mayer's hematoxylin were conducted.

Based on the histological grading proposed by Bryne et al. ${ }^{8}$, two observers identified the front of tumor invasion (light microscopy - Olympus CX-31) and at a 1000x magnification and analyzed the presence or absence of immunostaining in the cell membrane, cytoplasm, nucleus or a combination of these. Then, it was performed a semi-quantitative analysis of the $ß$-catenin protein expression according to the technique described by Lee et al. ${ }^{9}$, adapted for this study. It was considered as immunostained the cell with color ranging from dark yellow to brown, regardless of staining intensity. It was assigned therefore the following scores: " 0 ”, when less than $10 \%$ of the cells were immunostained, "+”, when between 10 to $50 \%$ of the cells were immunostained; and “++”, when more than $50 \%$ of the cells were immunostained.

\section{Statistical analysis}

The results were statistically analyzed by the software STATISTICA 6.0 (StarSoft Inc.), using the nonparametric U Mann-Whitney test for exploratory descriptive analysis. It was considered statistically significant a p value less than 0.05 .

\section{Results}

Data related to $ß$-catenin immunoexpression are shown in Table 1 and Figures 1 and 2. It was observed a variable expression in relation to the topography of $ß$-catenin, which was detected in cytoplasmic membrane, cell nucleus or both (Figures 3 to 6). However, there was not identified significant statistical differences in the topography of ß-catenin immunosuppression between the groups analyzed $(\mathrm{p}=0.9539)$.

TABLE 1 - Scores of ß-catenin immunoexpression in the group with metastasis and group without metastasis

\begin{tabular}{ccc|ccc}
\hline \multicolumn{3}{c|}{ Group with Metastasis } & \multicolumn{3}{c}{ Group without Metastasis } \\
\hline Case & Score & Location & Case & Score & Location \\
\hline 1 & 0 & - & 1 & + & $\mathrm{M}^{*} / \mathrm{C}$ \\
2 & + & $\mathrm{M} / \mathrm{C}^{*}$ & 2 & + & $\mathrm{M}$ \\
3 & + & $\mathrm{M}$ & 3 & 0 & - \\
4 & + & $\mathrm{M}$ & 4 & + & $\mathrm{C} / \mathrm{N}$ \\
5 & + & $\mathrm{M}$ & 5 & 0 & - \\
6 & 0 & - & 6 & 0 & - \\
7 & + & $\mathrm{M} / \mathrm{C}^{*}$ & 7 & 0 & - \\
8 & 0 & - & 8 & + & $\mathrm{M}$ \\
9 & ++ & $\mathrm{M} / \mathrm{C}$ & 9 & 0 & - \\
10 & ++ & $\mathrm{M} / \mathrm{C}^{*} / \mathrm{N}$ & 10 & ++ & $\mathrm{C}$ \\
11 & + & $\mathrm{M} / \mathrm{C}$ & 11 & ++ & $\mathrm{M} / \mathrm{C}$ \\
12 & 0 & - & 12 & ++ & $\mathrm{M} / \mathrm{N} / \mathrm{C}$ \\
\hline
\end{tabular}

$\mathbf{0}=$ no staining or insignificant $++=$ positive; $++=$ strongly positive;

* = predominance of the staining; $\mathbf{M}=$ staining on cell membrane;

$\mathbf{N}=$ staining in nucleus; $\mathbf{C}=$ staining in cytoplasm. 


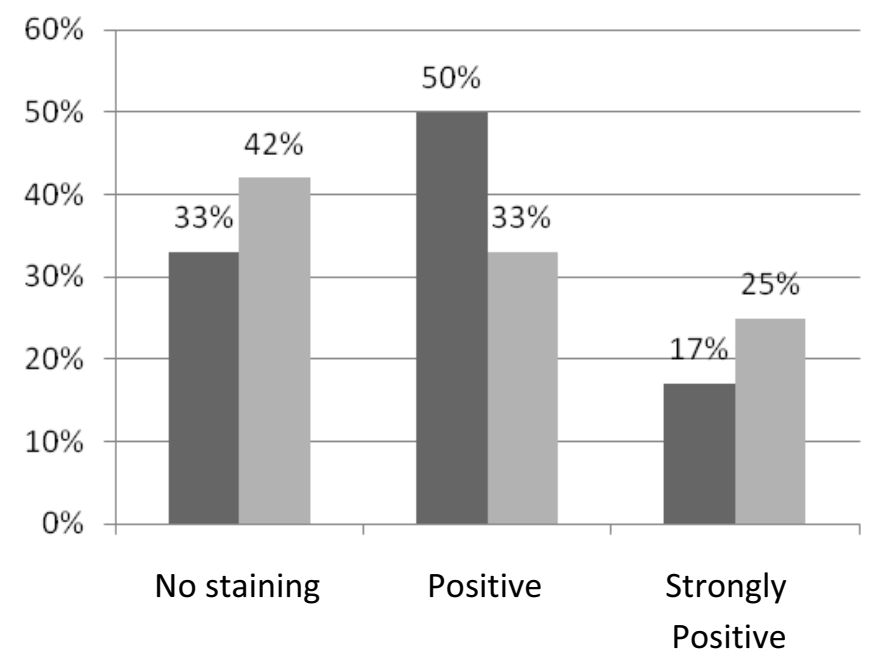

- Group with Metastasis

Group without Metastasis

FIGURE 1 - Percentual distribution of ß-catenin scores in the groups with metastasis and without metastasis

\section{Group with Metastasis}

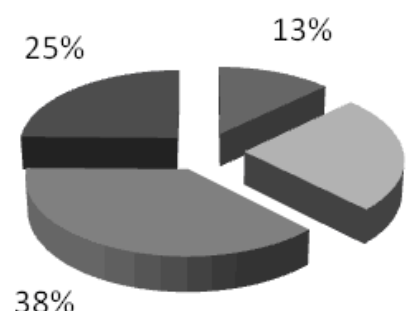

$25 \%$

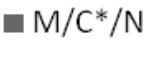

$\mathrm{M} * / \mathrm{C}$

$\mathrm{M}$

$\square \mathrm{M} / \mathrm{C}^{*}$

\section{Group without Metastasis}

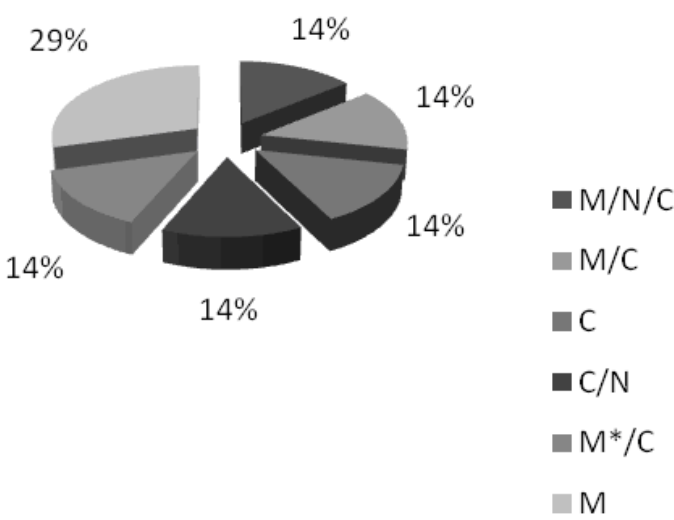

FIGURE 2 - Representation of the ß-catenin immunoexpression location in the group with metastasis and in the group without metastasis ( $\mathbf{M}=$ staining on cell membrane; $\mathbf{N}=$ staining in nucleus; $\mathbf{C}=$ staining in cytoplasm; * = predominance of the staining)

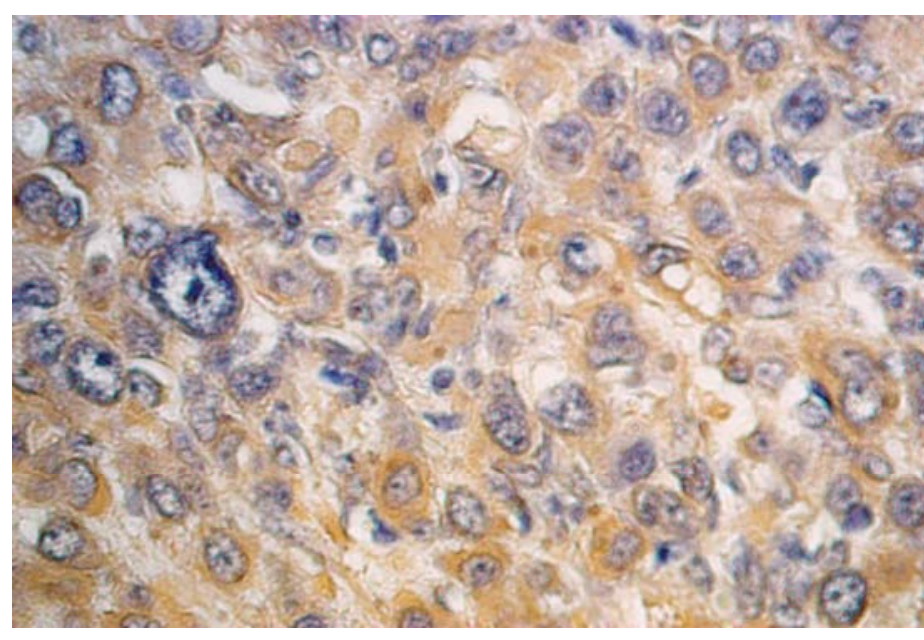

FIGURE 3 - Intense expression of ß-catenin in metastatic group of tongue OSCC. Cytoplasmic and membrane reaction (score ++ ) (streptavidin-biotin, original magnification $\times 400$ )

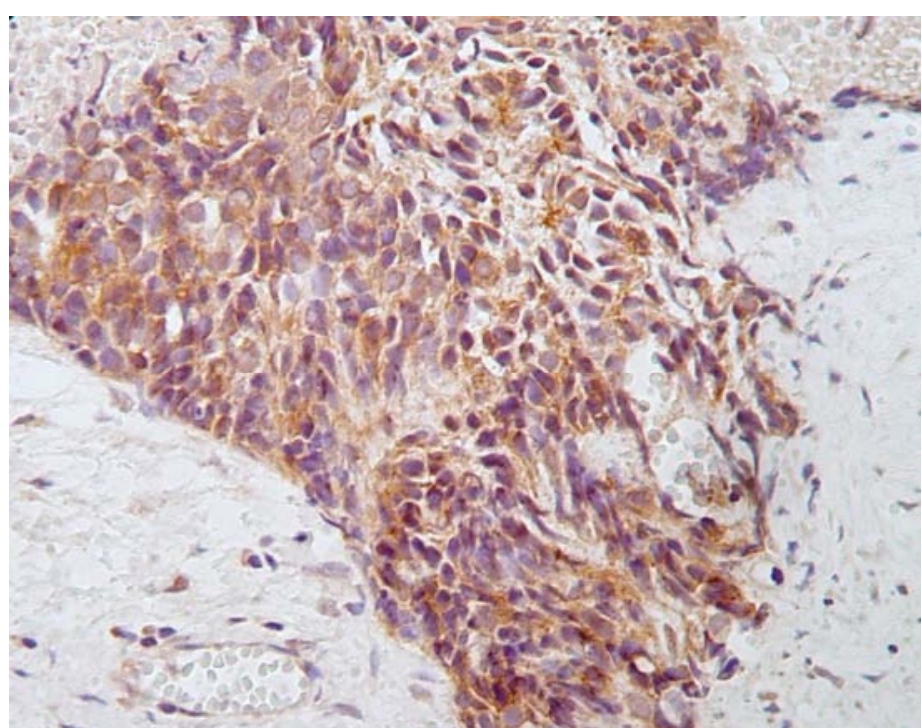

FIGURE 4 - Strong expression $ß$-catenin in the group without metastasis $($ Score ++ ) (streptavidin-biotin, original magnification $\times 200)$ 


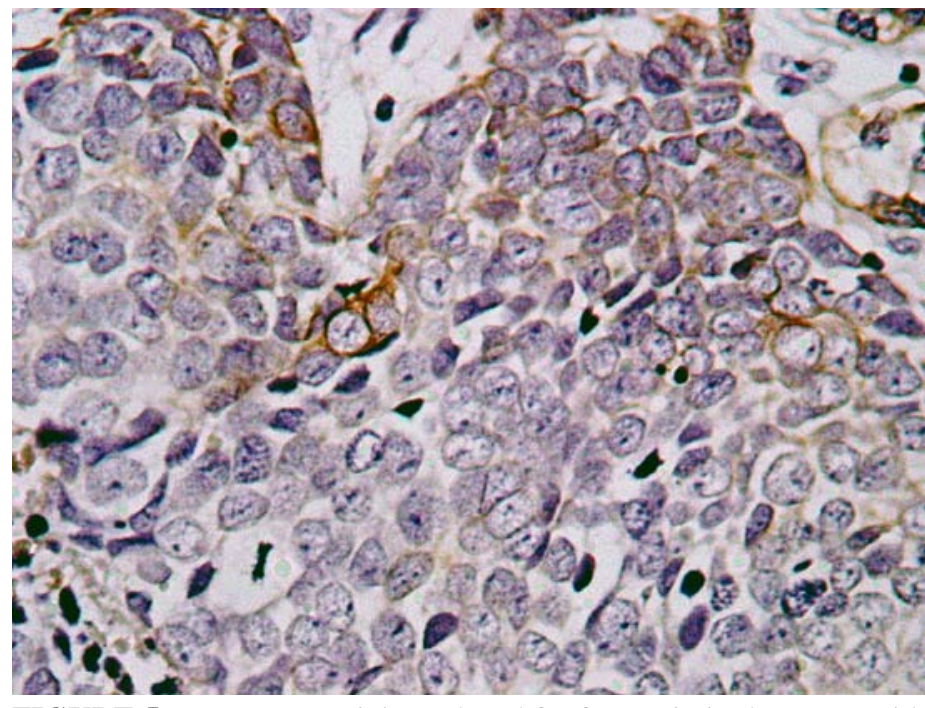

FIGURE 5 - Immunoreactivity reduced for ß-catenin in the group with metastasis $($ Score +$)$ (streptavidin-biotin, original magnification $\times 100$ )

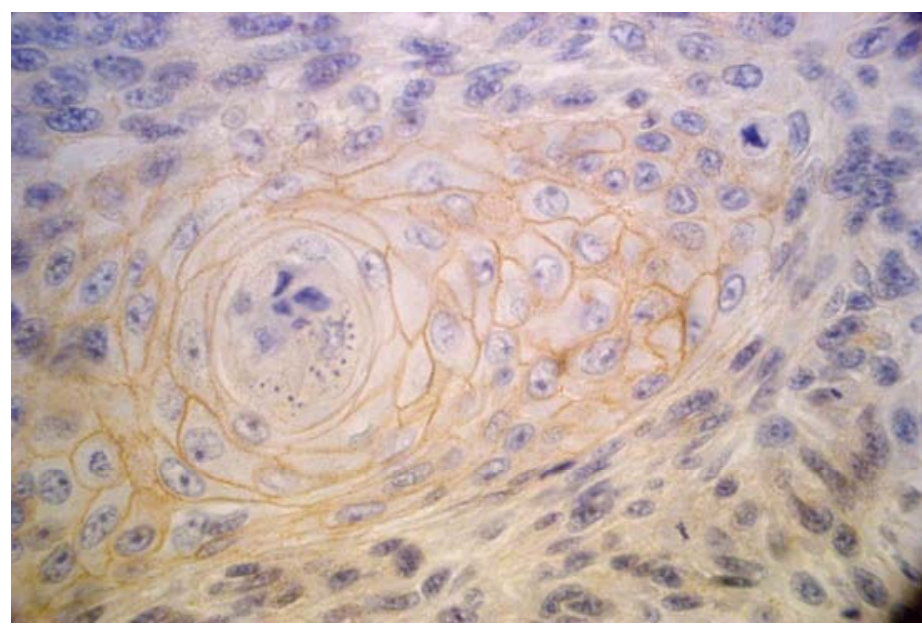

FIGURE 6 - Staining of $ß$-catenin in the central portion of tongue OSCC without metastasis (Score + ) (streptavidin-biotin, original magnification $\times 200$ )

\section{Discussion}

It has been shown a close association between the reduction of the intercellular adhesion and the loss of cell differentiation, accompanied by a greater mobility and invasion potential of neoplastic epithelial cells in several types of human malignancies, including OSCC ${ }^{6}$. One of the molecules related to cell adhesion is ß-catenin, with a dichotomous effect: it is able not only to actively participate in the process of intercellular adhesion but also related to intracellular signals transduction.

In our study, a clear reduction of $ß$-catenin reactivity was observed. More than $80 \%$ of the lesions in the group with metastasis and $75 \%$ of lesions in the group without metastasis had a score "0" or "+". Overall, these results are in line with other studies of OSCC, as has been observed reduced expression of $ß$-catenin molecule, with decreased levels ranging from $62 \%$ to $85 \%$ in OSCC $^{4,10}$. However, the statistical analysis showed no significant differences between ß-catenin expression between the groups.

One possible explanation for the lack of difference in $ß$-catenin immunoexpression among the groups may be the sample selection. For this study, only patients with metastasis at diagnosis of carcinoma were selected to compose the metastatic group. In other words, patients with development of secondary tumors after the diagnosis of primary tumor were not considered, as well as patients with subclinical metastasis. Therefore, it was not detected a positive relationship of this protein with the tumor metastatic potential, which corroborates the results of previous studies $^{1,5,10,11}$. However, some studies were able to establish a statistically significant relationship between the decreased $ß$-catenin expression with metastasis ${ }^{12-14}$.

Different results can be also explained by the existence of variations in the methodology adopted in relation to the immunostaining analysis. Some researches used quantitative methods, while others used semi-quantitative techniques. In addition, there are studies which used a percentage distribution in relation to immunostaining, while others adopted single and absolute count of positive cells ${ }^{1}$.

Another factor that limits possible comparisons of data with previous studies is we analyzed only cases of OSCC in tongue, since the anatomical location of oral squamous cell carcinoma influences the biological behavior of this tumor ${ }^{15}$. It is also possible that the loss of intercellular adhesion is only one of the stages required for the occurrence of metastases. Soon, there could be a need for other phenomena, such as loss of cell adhesion to the extracellular matrix, which can be caused by the metaloproteinases expression ${ }^{11}$.

According to what was found by Lopes et al. ${ }^{11}$, the presence of $ß$-catenin in nucleus and cytoplasm was a striking finding in this study, despite the lack of statistical correlation with metastatic potential. This fact suggests a possible role of $ß$-catenin in other tumor etiopathogenic aspects that are not exclusively related to the formation of metastasis, such as cell proliferation and angiogenesis. These processes need studies to assess these relationships in an attempt to better understand the clinical value of altered expression of ß-catenin in OSCC.

\section{Conclusion}

In view of these findings, it is appropriate to infer that the individual analysis of the $ß$-catenin immunoexpression does not represent a good criterion to predict the metastatic potential of tongue OSCC to the extent that there was no significant difference in its expression in the groups with metastasis and without metastasis.

\section{References}

1. Mahomed F, Altini M, Meer S. Altered E-cadherin/ß-catenin expression in oral squamous carcinoma with and without nodal metastasis. Oral Dis. 2007;13:386-92.

2. Dantas DD, Ramos CC, Costa AL, Souza LB, Pinto LP. Clinicalpathological parameters in squamous cell carcinoma of the tongue. Braz Dent J. 2003;4(1):22-5. 
3. Curran S, Murray GI. Matrix metalloproteinases: mollecular aspects of their roles in tumour invasion and metastasis. Eur J Cancer. 2000;36:1621-30.

4. Andrews NA, Jones AS, Helliwell TR, Kinsella AR. Expression of the E-cadherin-catenin cell adhesion complex in primary squamous cell carcinomas of the head and neck and their nodal metastasis. Br J Cancer. 1997;75(10):1474-80.

5. Kurtz KA, Hoffman HT, Zimmerman MB, Robinson RA. Decreased E-cadherin but not $ß$-catenin expression is associated with vascular invasion and decreased suvival in head and neck squamous carcinomas. Otolaryngol Head Neck Surg. 2006;134:142-6.

6. Beavon IRG. The E-cadherin-catenin complex in tumour metastasis: estruture, function and regulation. Eur J Cancer. 2000;36:1607-20.

7. Gao S, Eiberg H, Krogdahl A, Liu CJ, Sørensen JA. Cytoplasmic expressin of E-cadherin and $ß$-catetin correlated with $\mathrm{LOH}$ and hypermethylation of the APC gene in oral squamous cell carcinomas. J Oral Pathol Med. 2005;34:116-9.

8. Bryne M, Koppang HS, Lilleng R, Stene T, Bang G, Dabelsteen E. New malignancy grading is a better prognostic indicator than Broders' grading in oral squamous cell carcinoma. J Oral Pathol Med. 1989;18(8):432-7.

9. Lee CM, Shuarstamn H, Deavers MT, Wang SC, Xia W, Schmandt R, Bodurka DC, Atkinson EN, Malpica A, Gershenson DM, Hung MC, Lu $\mathrm{KH}$. ß-catenin nuclear localization is associated with grade in ovarian serous carcinoma. Gynecol Oncol. 2003;88(3):363-8.
10. Chow V, Yuen APW, Lam KY, Tsao GSW, Ho WK, Wei WI. A comparative study of the clinicopathological significance of E-cadherin and catenins (alpha, beta, gamma) expression in the surgical management of oral tongue carcinoma. J Cancer Res Clin Oncol. 2001;127(1):59-63.

11. Lopes FF, Miguel MCC, Pereira ALA, Cruz MCFN, Freitas RA, Pinto LP, Souza LB. Changes in immunoexpression of E-cadherin and ß-catenin in oral squamous cell carcinoma with and without nodal metastasis. Ann Diagn Pathol. 2009;13:22-9.

12. Odajima T, Sasaki Y, Tanaka N, Kato-Mori Y, Asanuma H, Ikeda T, Satoh M, Hiratsuka H, Tokino T, Sawada N. Abnormal ß-catenin expression in oral cancer with no gene mutation: correlation with expression of cyclin D1 and epidermal growth factor receptor, Ki-67 labeling index, and clinicopathological features. Human Pathol. 2005;36:234-41.

13. Ueda G, Sunakawa H, Nakamori K, Shinya T, Tsuhako W, Tamura Y, Kosugi T, Sato N, Ogi K, Hiratsuka H. Aberrant expression of ß- and $\gamma$-catenin is an independent prognostic marker in oral squamous cell carcinoma. Int J Oral Maxillofac Surg. 2006;35:356-61.

14. Cai Z, Shi X, Gao Y, Wei M, Wang C, Yu G. ß-catenin expression pattern in primary oral squamous cell carcinoma. Chin Med J. 2008;121(19):1866-70.

15.Bánkfalvi A, Krassort M, Buchwalow IB, Végh A, Felszeghy E, Piffkó J. Gains and losses of adhesion molecules (CD-44, E-cadherin and ß-catenin) during oral carcinogenesis and tumour progression. J Pathol. 2002;98(3):343-51.

Conflict of interest: none

Financial source: none

\section{Correspondence:}

Prof. Dr. Rivadávio Fernandes Batista de Amorim

Departamento de Patologia

Faculdade de Medicina, Universidade de Brasília

Asa Norte

70910-900 Brasília - DF Brasil

Phone: (55 61)3307-2560

rivadavioamorim@hotmail.com

Received: March 17, 2010

Review: May 18, 2010

Accepted: June 22, 2010

\section{How to cite this article}

Freitas RA, Silveira EJD, Silveira JPB, Silva FM, Amorim RFB. Correlation of ß-catenin expresssion and metastasis in tongue squamous cell carcinoma. Acta Cir Bras. [serial on the Internet] 2010 Nov-Dec;25(6). Available from URL: http://www.scielo.br/acb 